\title{
Chemotherapy Induced Peripheral Neuropathy in Breast Cancer Patients
}

\author{
Amani Saleh Hadi Saeed* \\ Specialist of Clinical Oncology and Nuclear Medicine, National Oncology Center-Aden, Yemen
}

Submission: June 01, 2021; Published: June 22, 2021

*Corresponding author: Amani Saleh Hadi Saeed, Specialist of Clinical Oncology and Nuclear Medicine, National Oncology Center-Aden, Yemen

\section{Mini Review}

For people with breast cancer, the most common cause of uncomfortable or even painful neuropathy that limits activity is chemotherapy -often referred to as chemotherapy -associated peripheral neuropathy. The main symptoms of chemotherapy -induced peripheral neuropathy CIPN may depend on the drug and dose used, but usually manifest as predominately distal weakness, loss of sensation and reflexes, discontinuation of the drug which induced peripheral neuropathy appears to suppress the symptoms, however, the remaining signs of toxicity should be observed taking heed of the presence of present injury [1,2]. In about $30 \%$ of patients, CIPN symptom may persist for six months and longer after completion of neurotoxic chemotherapy [3]. CIPN is one of the major dose limited side effects of many chemotherapeutic agents including platinum analogues, vinca alkaloids and taxanes [4]. most symptom related to peripheral neuropathy:

- $\quad$ Tingling (or apins and needles feeling)

- $\quad$ Burning or warm feeling

- Numbness

- Weakness

- $\quad$ Discomfort or pain

- $\quad$ Less ability to fell hot and cold

- $\quad$ Cramps (in your feet)

Diagnosis of peripheral neuropathy by different neurophysiology test such as:

i. Electromyography, nerve conduction studies, and quantitative sensory tests to further examine peripheral nerve function.

ii. Laboratory tests to look for metabolic disturbance and nutritional deficiencies. iii. Imaging tests to look for other possible cause of nerve damage.

Treatment and prevention: there are no high-quality studies demonstrating effective prevention of CIPN using any agent. The latest guidelines from the American Society of Clinical Oncology (ASCO) acknowledge this limitation and recommend against offering any CIPN-preventive drug to patients undergoing neurotoxic cancer treatment [5]. Regrading treatment of CIPN, the ASCO guidelines state that clinicians may offer duloxetine to symptomatic patients [6]. And should consider offering tricyclic antidepressants, gabapentin, or pregabalin to manage the positive symptoms associated with CIPN; however, these agents have no effect on the motor symptoms or the negative sensory symptoms. Patients should be informed of the limited scientific evidence of benefit from these anti-CINP drug, and of their potential harms and associated costs [5]. Proper and well -evaluated approaches would also produce a consistent advantage for both doctors and patients to allow the registration and analysis of reliable data on the incidence, prevalence, risk factors and long-term impact of CIPN, eventually leading to both potential preventive and therapeutic multidimensional interventions.

\section{References}

1. Schestatsky P, Zanonato A, Llado'-Carbo A, Polineuropatias (2009) In: Chavez ML, Finkelsztejn A, Stefani MA. Ratinas em neurologia e neurocirurgia. Porto Alerge: Artmed pp. 223-34.

2. Kimura J (1989) Electrodiagnosis in diseases of nerve and muscle: principles and practice. ( $2^{\text {nd }}$ edn). FA Davis; 1989 Chapter 25, polyneuropathies, Philadelphia, USA, pp.462-81.

3. Serenty $\mathrm{M}$ et al. incidence, prevalence, and predictor of chemotherapy -induced peripheral neuropathy: asymptotic review and meta-analysis. Pain 155: 2461-2470.

4. Hausheer FH, Schilsky RL, Bain S, Berghorn EJ Lieber man F (2006) Diagnosis, management, and evaluation of chemotherapy -inducedperphiral neuropathy. semin Onco 33(1): 15-49. 


\section{Cancer Therapy \& Oncology International Journal}

5. Hershman D, Lacchetti C, Dworkin R, et al. (2014) prevention and management of chemotherapy -induced peripheral neuropathy in survivors of adult cancers: American Society of Clinical Oncology Clinical Practice Guideline. J clin Oncol 32: 1941-1967.
6. Smith EM, Pang H, Cirrncion C et al. (2013) Effects of duloxetine on pain, function and quality of life among patients with chemotherapy -induced painful peripheral neuropathy : randomized clinical trial JAMA 309: 1359-1367.

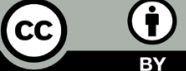

This work is licensed under Creative Commons Attribution 4.0 License DOI:10.19080/CTOIJ.2021.19.556006
Your next submission with Juniper Publishers will reach you the below assets

- Quality Editorial service

- Swift Peer Review

- Reprints availability

- E-prints Service

- Manuscript Podcast for convenient understanding

- Global attainment for your research

- Manuscript accessibility in different formats ( Pdf, E-pub, Full Text, Audio)

- Unceasing customer service

Track the below URL for one-step submission https://juniperpublishers.com/online-submission.php 